\title{
PREVALENCE OF DEPRESSION IN PATEINTS WITH CHRONIC BACKACHE
}

\author{
Sandip Subedi, ${ }^{1}$ Alok Pandey, ${ }^{2}$ Shirish Aryal $^{3}$
}

\begin{abstract}
\section{INTRODUCTION}

Backache is a common problem with about $70 \%$ of people in developed countries experience low back pain at some time in their lives. A number of studies done previously shows that there is high prevalence of depression in patients with chronic backache. This study was carried out to find out the prevalence of depression in patients with chronic backache in Nepalese subjects.
\end{abstract}

\section{MATERIAL AND METHODS}

This was a cross-sectional descriptive study conducted in Universal College of Medical Sciences, Bhairahawa, Nepal. Patients presenting to Orthopaedics OPD with history of backache lasting for more than 12 weeks were referred for psychiatric evaluation. One hundred cases were included in the study based on inclusion / exclusion criteria in six months period (from $1^{\text {st }}$ Jan 2019 to $30^{\text {th }}$ June 2019). Detailed evaluation was done by a psychiatrist to find out the presence of depression. Diagnosis of depression was made based on ICD-10 DCR. Data was analysed using SPSS.

\section{RESULTS}

Out of total 100 subjects, more than half (56\%) were females. Majority of the subjects (61\%) were below 45 years of age. The average age of the subjects was 45 years minimum age being 16 and maximum 77 . About $59 \%$ were also suffering from depressive disorder.

\section{CONCLUSION}

This study concludes that significant number of patients with chronic backache attending OPD of tertiary care hospital suffers from depression. It is therefore essential to screen for depression in these patients.

KEYWORDS Depression, Chronic Backache, Nepal

1. Department of Psychiatry, Universal College of Medical Sciences, Bhairahawa, Nepal

2. Department of Orthopaedics, Universal College of Medical Sciences, Bhairahawa,Nepal

3. Department of Psychiatry, Janaki Medical College, Janakpur, Nepal

DOI: http//doi.org/10.3126/jucms.v7i2.27106

\author{
For Correspondence \\ Dr. Sandip Subedi \\ Department of Psychiatry \\ Universal College of Medical Sciences \\ Bhairahawa, Nepal \\ E-mail: sandipsubedi@hotmail.com
}




\section{INTRODUCTION}

Back pain is a common problem with about $70 \%$ of people in developed countries experience low back pain at some time in their lives. ${ }^{1}$ Any kind of pain which lasts for longer than three months, that accompanies a disease process, or that is associated with a bodily injury that has not resolved over time may be referred to as chronic pain. ${ }^{2}$ Many Individuals suffering from chronic pain often find it difficult and report that pain interferes with their ability to engage in occupational, social, romantic, or recreational activities, which is consistent with a bio-psychosocial model of illness. Their inability to engage in these reinforcing activities may contribute to increased isolation, feelings of worthlessness, and depressed mood. A number of studies done concludes that approximately $27 \%$ of patients with pain in primary care clinics meet criteria for major depression. ${ }^{3}$ This study was done to explore the prevalence of depression in patients with chronic low backache in Nepalese population.

\section{MATERIAL AND METHODS}

This was a cross-sectional descriptive study conducted with convenient sampling method in Universal College of Medical Sciences, Bhairahawa, Nepal in six months period (from $1^{\text {st }}$ Jan 2019 to $30^{\text {th }}$ June 2019). Patients presenting to Orthopaedics OPD with history of backache lasting for more than 12 weeks were referred for Psychiatric evaluation and included in the study based on inclusion / exclusion criteria. One hundred consecutive patients were enrolled for the study after receiving written informed consent from each individual. Ethical clearance was obtained from the Institutional Review Board. The information were kept confidential.

A semi-structured performa designed for the purpose was used to record the basic socio-demographic details. Detailed psychiatric work-up was done in all subjects. The final psychiatric diagnoses were made according to the International classification of disease and infirmity, $10^{\text {th }}$ edition (ICD-10) criteria. Data were entered into a computer and analyzed using Statistical Package for Social Science (SPSS) software.

\section{RESULTS}

Majority of the subjects (61\%) were below 45 years of age. The average age of the subjects was 45 years minimum age being 16 and maximum 77 . More than half $(56 \%)$ of the subjects were females. Most of the subjects were Hindu (81\%) by religion and belong to middle socio-economic status $(66 \%)$. Significant proportions of these Nepalese patients were illiterate or less educated. About half (44\%) of the subjects were housewives and living in semi-urban area. Many of the subjects (53\%) were living in a joint family.
Details of the sociodemographic profile is shown in Table 1.

Table 1. Showing socio-demographic distribution of subjects

\begin{tabular}{|c|c|c|}
\hline & $\begin{array}{l}\text { No of ca } \\
\text { Percenta }\end{array}$ & $\begin{array}{l}\text { es }(n=100) \\
\text { e }(\%)\end{array}$ \\
\hline Age group & $18-44$ & 61 \\
\hline & $45-64$ & 31 \\
\hline & $>65$ & 8 \\
\hline & Total & 100 \\
\hline Gender & Male & 44 \\
\hline & Female & 56 \\
\hline & Total & 100 \\
\hline Religion & Buddhist & 2 \\
\hline & Hindu & 81 \\
\hline & Islam & 17 \\
\hline & Total & 100 \\
\hline Marital status & Married & 97 \\
\hline & Unmarried & 3 \\
\hline & Total & 100 \\
\hline Socio-economic status & High & 7 \\
\hline & Low & 27 \\
\hline & Middle & 66 \\
\hline & Total & 100 \\
\hline Education & Illiterate & 39 \\
\hline & Primary & 13 \\
\hline & Secondary & 31 \\
\hline & Higher Secondary & 6 \\
\hline & Above Higher Secondary & 11 \\
\hline & Total & 100 \\
\hline Occupation & Housewife & 44 \\
\hline & Job holder & 22 \\
\hline & Farmer & 15 \\
\hline & Business & 16 \\
\hline & Student & 3 \\
\hline & Total & 100 \\
\hline Domicile & Rural & 41 \\
\hline & Urban & 13 \\
\hline & Semi-urban & 46 \\
\hline & Total & 100 \\
\hline Family type & Extended & 6 \\
\hline & Joint & 54 \\
\hline & Nuclear & 40 \\
\hline & Total & 100 \\
\hline
\end{tabular}

The average duration of backache was 25.2 months and maximum duration being 20 years. Asking about the severity of backache, $31 \%$ of subjects had severe backache and $42 \%$ had moderate backache. There were severe dysfunction due to backache in about $25 \%$ subjects and moderate dysfunction in about 46\% subjects. Among 100 subjects suffering from chronic backache, $60 \%$ were also suffering depressive disorder. Thirty-nine percent were suffering from mild depression, 16\% moderate depression and 5\% subjects were suffering from severe depression. Detail of the clinical profile is seen in Table 2 . 
Table 2. Showing clinical profile of patients with chronic low backache

\begin{tabular}{lll}
\hline Duration of backache & Upto 6 months & 45 \\
\hline & $6-12$ months & 18 \\
$1-2$ yrs & 13 \\
$2-3$ yrs & 8 \\
-3 yrs & 16 \\
& Total & $\mathbf{1 0 0}$ \\
Severity of backache & mild & 27 \\
& moderate & 42 \\
& Severe & 31 \\
Degree of & Total & $\mathbf{1 0 0}$ \\
dysfunction & Mild & 25 \\
& & \\
& Moderate & 46 \\
Depression & Severe & 29 \\
& Total & $\mathbf{1 0 0}$ \\
& Mild & 39 \\
& Moderate & 16 \\
& Severe & 5 \\
& Total & $\mathbf{1 0 0}$
\end{tabular}

Depression showed significant association with degree of dysfunction $(p=0.018)$ and severity of backache $(p=0.017)$. Detail of the bivariate analysis is shown in Table 3.

Table 3. Showing bivariate analysis between depression and socio-demographic and clinical profile

\begin{tabular}{|c|c|c|c|c|c|c|}
\hline & & \multicolumn{2}{|c|}{ Depression } & \multirow[t]{2}{*}{ Total } & \multirow[t]{2}{*}{ Percentage } & \multirow[t]{2}{*}{$\begin{array}{l}\text { P- } \\
\text { value }\end{array}$} \\
\hline & & Absent & Present & & & \\
\hline \multirow[t]{3}{*}{$\begin{array}{l}\text { Degree of } \\
\text { dysfunction }\end{array}$} & Mild & 16 & 9 & 25 & 25 & 0.018 * \\
\hline & Moderate & 15 & 31 & 46 & 46 & \\
\hline & Severe & 9 & 20 & 29 & 29 & \\
\hline \multirow[t]{3}{*}{$\begin{array}{l}\text { Severity of } \\
\text { backache }\end{array}$} & Mild & 17 & 10 & 27 & 27 & 0.017 * \\
\hline & Moderate & 13 & 29 & 42 & 42 & \\
\hline & Severe & 10 & 21 & 31 & 31 & \\
\hline \multirow[t]{5}{*}{$\begin{array}{l}\text { Duration of } \\
\text { backache }\end{array}$} & $\begin{array}{l}\text { up to } 6 \\
\text { months }\end{array}$ & 18 & 27 & 45 & 45 & 0.066 \\
\hline & -12 months & 3 & 15 & 18 & 18 & \\
\hline & $-2 \mathrm{yr}$ & 9 & 4 & 13 & 13 & \\
\hline & $-3 y r$ & 3 & 5 & 8 & 8 & \\
\hline & 3 or more & 7 & 9 & 16 & 16 & \\
\hline \multirow[t]{3}{*}{ Family type } & Nuclear & 20 & 20 & 40 & 40 & 0.17 \\
\hline & Joint & 17 & 37 & 54 & 54 & \\
\hline & Extended & 3 & 3 & 6 & 6 & \\
\hline \multirow[t]{3}{*}{$\begin{array}{l}\text { Socio } \\
\text { economic } \\
\text { status }\end{array}$} & Low & 10 & 17 & 27 & 27 & 0.726 \\
\hline & Middle & 28 & 38 & 66 & 66 & \\
\hline & High & 2 & 5 & 7 & 7 & \\
\hline \multirow[t]{5}{*}{ Education } & Illiterate & 13 & 26 & 39 & 39 & 0.109 \\
\hline & Primary & 7 & 6 & 13 & 13 & \\
\hline & $\begin{array}{l}\text { Secondary } \\
\text { Higher }\end{array}$ & 16 & 15 & 31 & 31 & \\
\hline & $\begin{array}{l}\text { Secondary } \\
\text { More than } \\
\text { Higher }\end{array}$ & 0 & 6 & 6 & 6 & \\
\hline & Secondary & 4 & 7 & 11 & 11 & \\
\hline
\end{tabular}

\begin{tabular}{llrrrrr}
\hline & & \multicolumn{2}{c}{$\begin{array}{c}\text { Depression } \\
\text { Absent }\end{array}$} & Total & Present & P- \\
Parital status & & & & \\
Occupation & Unmarried & 0 & 3 & 3 & 3 & 0.151 \\
& Married & 40 & 57 & 97 & 97 & \\
& Housewife & 13 & 31 & 44 & 44 & 0.146 \\
& job holder & 10 & 12 & 22 & 22 & \\
& farmer & 5 & 10 & 15 & 15 & \\
& Business & 10 & 6 & 16 & 16 & \\
Domicile & Student & 2 & 1 & 3 & 3 & \\
& Rural & 16 & 25 & 41 & 41 & 0.336 \\
& Urban & 3 & 10 & 13 & 13 & \\
Mean age & Semi Urban & 21 & 25 & 46 & 46 & \\
\hline
\end{tabular}

\section{DISCUSSION}

Low back pain is something that almost all people experience at some point in their lives. It is something common across sexes, age groups, countries, socioeconomic groups, education levels and occupation.

Study by Chou $\mathrm{R}$ et $\mathrm{al}^{4}$ suggested that chronic pain is a debilitating condition with loss of productivity, decreased quality of life, and increased morbidity are some of the known effects of this condition.

This study found that there is a very high prevalence of depression in patient with chronic backache. The result of this study support the study done by Reddy et al. ${ }^{5}$

Chronic pain and depression most likely have a bidirectional association: depression is a predictor of persistent pain and pain is a predictor of the persistence of depression. ${ }^{6}$ A possible explanation is that impaired functioning caused by pain can lead to social isolation, which in turn can lead to a negative effect on depressive symptoms, and vice versa.

Depression and anxiety have been associated with magnification of medical symptoms whereas emotional distress has been connected to physical symptoms by means of autonomic arousal, vigilance and misinterpretation of somatic amplification.

The severity of the depressive and anxiety symptoms are significantly associated with pain-related disability and limiting pain, with more severe symptoms having higher odds for highly disabling and severely limiting pain. ${ }^{8}$

Depressive and anxiety disorders may add to pain as they increase the likelihood of social isolation, increased attention towards threat and avoidance of physical exertion. ${ }^{9,10}$

Depression and anxiety disorders also share the same pathophysiological pathways as pain. ${ }^{11-13}$ They facilitate the central modulation of the pain response, in the periaqueductal gray, amygdala, and hypothalamus, ${ }^{14,15}$ and when deficits 
occur in these areas, modulation of signals from the body are disturbed, leading to a more severe experience of pain. Although these brain areas all play a role in depression, anxiety, and pain, not every individual responds the same to pain stimuli. ${ }^{16-18}$ Some individuals are more sensitive to pain than others.

Furthermore, depression and anxiety induce stress and increases the production of pro-inflammatory cytokines, which may increase pain. ${ }^{19,20}$ The finding showing higher painrelated disability in co-morbid depression and anxiety in our study is similar to findings from the STAR*D studies. ${ }^{21,22}$

Taken together, these data indicate that depression is a common comorbidity in chronic backache and that the presence of depression significantly reduces the efficacy of a standard chronic pain treatment program. These findings suggest that psychiatric comorbid disorders need to be screened for and diagnosed. Results of this study do not indicate whether treatment of these disorders will impact treatment outcomes. However, until results from outcome studies are clear, these patients should be offered aggressive psychiatric treatment. The impact of early recognition and treatment of comorbid psychiatric disorders in the chronic pain management setting is, therefore, an important area that needs to be investigated further, since the importance of psychiatric care may be overlooked in many chronic pain programs.

\section{CONCLUSION}

Depression is a very common comorbidity in chronic backache. It suggests that every patient with Chronic backache needs to be screened for psychiatric illnesses.

\section{REFERENCES}

1. Andersson GBJ. The epidemiology of spinal disorders. In: Frymoyer JW, Ed. The adult spine: principles and practice. 2nd Ed. New York: Raven Press, 1997:93-141.

2. Merskey H, Bogduk N. Task Force on Taxonomy of the International Association for the Study of Pain. 2nd ed. Seattle: IASP Press; 1994.

3. Bair MJ, Robinson RL, Katon W, Kroenke K. Depression and pain comorbidity: a literature review. Arch Intern Med. 2003; $163: 2433-2445$.

4. Chou R, Shekelle P, Chou Roger, et al. Will this patient develop persistent disabling low back pain? JAMA. 2010;303:12951302.

5. Reddy LNI, Kumar C, Srikrishna MP, Singamsetty B. Psychiatric Morbidity among Chronic Low Backache PatientsACross Sectional Study. JMSCR. 2015;03:07:6900-6903.

6. Bair MJ, Robinson RL, Katon W, Kroenke K.Depression and pain comorbidity: a literature review. Arch Intern Med. 2003;163: 2433-2445.

7. Vlaeyen JW, Linton SJ. Fear-avoidance and its consequences in chronic musculosleletal pain: a state of the art. Pain. 2000;85:317-332.

8. de Heer EW, Gerrits MMJG, Beekman ATF, Dekker J, van Marwijk HWJ, et al. The Association of Depression and Anxiety with Pain: A Study from NESDA. PLoS ONE. 2014; 9(10): e106907.

9. Saito T, Kai I, Takizawa A. Effects of a program to prevent social isolation on loneliness, depression, and subjective wellbeing of older adults: a randomized trial among older migrants in Japan. Arch Gerontol Geriatr. 2012;55:539-547.

10. Jang Y, Haley WE, Small BJ, Mortimer JA. The role of mastery and social resources in the associations between disability and depression in later life. Gerontologist. 2012; 42:807-813

11. Bair MJ, Robinson RL, Eckert GJ, Stang PE, Croghan TW, et al. Impact of pain on depression treatment response in primary care. Psychosom Med. 2004;66:17-22.

12. Campbell LC, Clauw DJ, Keefe FJ. Persistent pain and depression: a biopsychosocial perspective. Biol Psychiatry. 2003;54:399-409.

13. Maes M, Yirmyia R, Noraberg J, Brene S, Hibbeln J, et al. The inflammatory \& neurodegenerative (I\&ND) hypothesis of depression: leads for future research and new drug developments in depression. Metab Brain Dis. 2009;24:27-53.

14. Ossipov MH, Dussor GO, Porreca F. Central modulation of pain. J Clin Invest. 2010;120:3779-3787.

15. Millan MJ. Descending control of pain. Prog Neurobiol. 2002;66:355-474.

16. Schulz E, Zherdin A, Tiemann L, Plant C, Ploner $\mathrm{M}$. Decoding an individual's sensitivity to pain from the multivariate analysis of EEG data. Cereb Cortex. 2012;22: 1118-1123.

17. Mogil JS. The genetic mediation of individual differences in sensitivity to pain and its inhibition. Proc Natl Acad Sci U S A. 1999;96:7744-7751.

18. Ziv M, Tomer R, Defrin R, Hendler T. Individual sensitivity to pain expectancy is related to differential activation of the hippocampus and amygdala. Hum Brain Mapp. 2010;31:326-338

19. Maes M, Song C, Lin A, De Jongh R, Van Gastel A, et al. The effects of psychological stress on humans: increased production of pro-inflammatory cytokines and a Th1-like response in stress-induced anxiety. Cytokine. 1998;10:313-318.

20. de Oliveira CM, Sakata RK, Issy AM, Gerola LR, Salomao R. Cytokines and pain. Rev Bras Anesthesiol. 2011;61:255-259, 260-255, 137-242. 
21. Fava M, Alpert JE, Carmin CN, Wisniewski SR, Trivedi MH, et al. Clinical correlates and symptom patterns of anxious depression among patients with major depressive disorder in STAR*D. Psychol Med. 2004;34:1299-1308.

22. Fava M, Rush AJ, Alpert JE, Carmin CN, Balasubramani GK, et al.What clinical and symptom features and comorbid disorders characterize outpatients with anxious major depressive disorder: a replication and extension. Can J Psychiatry. 2006;51:823-825 